\title{
Immunochemical detection of emerging organic contaminants in environmental waters
}

\author{
Zhen Zhang ${ }^{\text {a, b }}$, Kun Zeng ${ }^{\text {b }}$, Jingfu Liu ${ }^{\text {a, c, * }}$ \\ a State Key Laboratory of Environmental Chemistry and Ecotoxicology, Research Center for Eco-Environmental Sciences, Chinese Academy of Sciences, P. O. \\ Box 2871, Beijing 100085, China \\ b School of the Environment and Safety Engineering, Jiangsu University, Zhenjiang 212013, China \\ c Institute of Environment and Health, Jianghan University, Wuhan, Hubei Province, 430056, China
}

\section{A R T I C L E I N F O}

Article history:

Available online 18 December 2016

\section{Keywords:}

Emerging organic contaminants

Immunochemical technique

Antibody-like binders

Enzyme-linked immunosorbent assays

Time-resolved fluoroimmunoassay

Immunosensors

High throughput screen

Risk assessment

\begin{abstract}
A B S T R A C T
Immunochemical techniques exhibit great advantages of high efficiency, rapidness, reliability and low cost compared to instrumental methods for monitoring emerging organic contaminants (EOCs) in aquatic environments. This review covers recent advances in applying traditional and other antibody-like binders against these organic pollutants, and various antibody-based immunochemical methods such as enzyme-linked immunosorbent assays, time-resolved fluoroimmunoassay and immunosensors. Moreover, we also discuss the advantages and disadvantages of techniques for antibody production and analytical methods, and covers promising future prospects.
\end{abstract}

๑) 2016 Elsevier B.V. All rights reserved.

\section{Introduction}

Emerging organic contaminants (EOCs) are unregulated organic pollutants, including antibiotics, personal care products, surfactants and surfactant residues, artificial sweeteners, pesticides, steroids and various industrial additives. These chemicals exist in the environment in unknown quantities and lack extensive ecotoxicological data, and they are also discharged into the aquatic environment that could lead to potential adverse ecological or human health effects [1-3].

Due to their low concentration in aquatic system and the presence of other contaminants, EOCs have to be enriched and cleaned from water samples prior to instrumental analysis. The most commonly used pretreatment method is solid phase extraction (SPE), which has been coupled with many instrumental analytical techniques such as liquid chromatography tandem mass spectrometry (LC-MS/MS) $[4,5]$ and gas chromatography mass spectrometry (GC-MS) [6,7] for the detection of EOCs in environmental waters. Although these approaches possess the advantages of high

\footnotetext{
* Corresponding author. State Key Laboratory of Environmental Chemistry and Ecotoxicology, Research Center for Eco-Environmental Sciences, Chinese Academy of Sciences, P. O. Box 2871, Beijing 100085, China. Fax: +86 1062849192

E-mail address: jfliu@rcees.ac.cn (J. Liu).
}

sensitivity for both quantification and identification, they suffer from several limitations including (i) low throughput that cannot address the backlog of samples that need to be analyzed; (ii) large volume of each sample to be enriched and complicated pretreatment procedures to separate targets from matrices; (iii) expensive instrumentation that requires skilled analysts and is unsuitable for field studies and on-line monitoring of target pollutants [8].

Antibody-based immunochemical techniques provide alternative analytical methods for these organic chemicals in environmental waters, and they have already been demonstrated to be quick, simple, sensitive and reliable [9-11]. To date, many effective immunochemical methods for EOCs have been established, and some have been used to simultaneously analyze a large number of samples in a short time, such as enzyme-linked immunosorbent assays (ELISA) and time-resolved fluoroimmunoassays [12,13]. In contrast to these high-throughput immunoassays, immunosensor techniques, including electrochemical and optical sensors, use simple, portable and robust devices to carry out on-site analysis on single samples [14]. All of these techniques have been used to screen environmental EOCs, and share common features: miniaturization, automation, and sophisticated analysis without complex sample preparation [15].

In this review article, we describe some classical and novel techniques in the production of traditional antibodies and other binders against EOCs. Emerging technologies with new binders are 
introduced as well. We also review EOC analysis in aquatic environments using high-throughput immunoassays and immunosensors.

\section{Antibodies for EOCs}

\subsection{Traditional antibodies}

Most antibodies against EOCs are traditional antibodies, including polyclonal antibodies (pAbs) and monoclonal antibodies (mAbs). pAbs are directly produced by hyperimmunized animals, while $m A b s$ are obtained from hybridoma cell lines. $\mathrm{mAbs}$ are superior to pAbs in immunoassays because (i) antiserums (pAbs) are limited but mAbs can be cloned indefinitely; (ii) mAbs are from identical offspring of a single cell with the same affinity and specificity to antigens, while pAbs are from different $B$ cells with diverse affinities that might result in undesirable matrix affects in immunoassay $[16,17]$. However, mAbs do not show better performance than pAbs in all aspects. For instance, mAbs require larger-scale screening strategies and are more expensive than pAbs, which is also the reason why pAbs are more widely used in bioanalytical applications for EOCs.

While some mAbs and pAbs are high-specific antibodies which show no or low cross-reactivities with similar-structure compounds, others are considered broad-specific antibodies or generic antibodies that can recognize multiple targets. The broad-specific antibodies are currently an area of active research because they can analyze several analogs in a single assay.

EOCs are small molecular weight compounds which are nonimmunogenic and cannot be used to elicit an immune response by directly injecting animals. Thus, EOCs have to be conjugated with carrier proteins (e.g., bovine serum albumin, BSA; egg albumin, OVA; human serum albumin, HSA) to form artificial complete antigens. Considering that some target chemicals have no functional group (carboxy-, amino-, hydrosulfuryl-) in their molecular structures to bind proteins. They usually have to be modified in order to be coupled with carrier proteins called haptens. Therefore, appropriate design and synthesis of haptens is the key step in antibody production, which could influence the affinity and specificity of the antibody as well as its performance in an immunoassay [18]. In immunology it is widely accepted that antibodies preferentially recognize the part of molecule that is the farthest away from the hapten. Therefore, the main strategy is to make the group with common or similar molecular structure or spatial conformation furthest away from the hapten.

In order to get broad-specificity antibodies against structurally similar compounds, computer-assisted molecular modeling techniques have been used as a reliable tool to study steric and electronic characteristics of haptens, mimic the target molecule structures, and aid in the design of haptens [19]. For instance, based on molecular modeling, Wang et al. selected ciprofloxacin as an optimal hapten to synthesize an immunogen. After immunizing female BALB/c mice with the immunogen, mAbs with high crossreactivity (35-100\%) were obtained. Furthermore, they explained the mechanism of specificity of this mAb by evaluating its conformational and electronic properties [20]. Adrian et al. also synthesized haptens against the common aminobenzenesulfonylamino moieties with the aid of theoretical calculations and molecular modeling tools, based on the haptens, they generated pAbs that showed high sensitivity and excellent cross-reactivity to recognize 10 sulfonamides directly [21]. Other selected examples of the antibodies against EOCs are listed in Table 1.

The generic antibodies focus on chemicals with closely-related molecular structures. In contrast to the approaches above, another approach to generate an antibody capable of
Table 1

Antibodies produced for EOCs with conventional methods.

\begin{tabular}{llll}
\hline Class & Organic pollutant & Antibody & Ref \\
\hline Pharmaceutical & Sulfonamides & $\mathrm{mAb}$ & {$[22]$} \\
& Carbamazepine & $\mathrm{mAb}$ & {$[13]$} \\
& Progesterone & $\mathrm{mAb}$ & {$[23]$} \\
& Quinolones & $\mathrm{mAb}$ & {$[24]$} \\
& Cephems & $\mathrm{pAb}$ & {$[25]$} \\
& Indomethacin & $\mathrm{pAb}$ & {$[26]$} \\
& Tetracycline & $\mathrm{pAb}$ & {$[27]$} \\
& Nitrofurantoin & $\mathrm{pAb}$ & {$[28]$} \\
& Progesterone & $\mathrm{pAb}$ & {$[29]$} \\
& Imidaclothiz & $\mathrm{mAb}$ & {$[30]$} \\
& Deltamethrin & $\mathrm{mAb}$ & {$[31]$} \\
& Carbofuran & $\mathrm{mAb}$ & {$[32]$} \\
& Flucythrinate & $\mathrm{mAb}$ & {$[33]$} \\
& Methiocarb & $\mathrm{mAb}$ & {$[34]$} \\
& Fenarimol & $\mathrm{pAb}$ & {$[35]$} \\
& Imidacloprid & $\mathrm{pAb}$ & {$[36]$} \\
& Chlorpyrifos & $\mathrm{pAb}$ & {$[37]$} \\
& Di-(2-ethylhexyl) phthalate & $\mathrm{mAb}$ & {$[38]$} \\
& Bisphenol A & $\mathrm{mAb}$ & {$[39]$} \\
& Dimethyl phthalate & $\mathrm{pAb}$ & {$[40]$} \\
& Nonylphenol & $\mathrm{pAb}$ & {$[41]$} \\
& Triclosan & $\mathrm{pAb}$ & {$[42]$} \\
\hline \multirow{2}{*}{ Personal care product } & &
\end{tabular}

simultaneously recognizing compounds with diverse molecular structures is to conjugate several haptens to the same carrier protein [43]. However, the challenge of this approach is how to control the number of each hapten derivative binding to the correspondent carrier protein, even the value of hapten to protein conjugates could be identified by MOIDI-TOF/MS through comparing the observed molecular weights of the prepared conjugates with the unreacted protein [44].

\subsection{Other antibody-like binders}

Compared to traditional antibodies, other types of antibodies, or novel antibody-like biological and synthetic binders have been developed, such as molecularly imprinted polymers, nanobodies, aptamers, protein scaffolds and recombinant antibodies. Most of these techniques have been used in immunotherapeutic and immunodiagnostic applications because of their high affinity and specificity [45]. Fodey et al. gave a comprehensive review of the progress and use of nanobodies, aptamers, and protein scaffolds in environmental detection. Although they stated that recombinant antibodies have achieved significant success in biomedicine, the defects of their biophysical properties and complicated molecular composition could hamper further development [17]. However, recombinant antibodies have characteristics that make them potentially useful for EOC analysis.

Recombinant antibodies are genetically engineered antibodies. The genes can be amplified by PCR and expressed through different expression systems to various formats, such as the antigen binding fragments (Fab), the bare variable fragment $(\mathrm{Fv})$, the variable domain of heavy chain $\left(\mathrm{V}_{\mathrm{H}}\right)$ and the single chain variable fragment $(\mathrm{scFv})$, as shown in Fig. 1. Different recombinant antibody fragments, like different formats of functional binding molecules, can effectively capture their corresponding targets similar to traditional antibodies. At the same time, recombinant antibody technology shows many advantages over traditional antibodies in the following aspects: (i) Recombinant antibodies can be adjusted through molecular biology techniques for expression, posttranslational modification, optimization in affinity and specificity according to the application [45]; (ii) Recombinant antibodies can be generated in vitro via phage and bacterial display systems, making the selection and screening procedure flexibly [46]. 


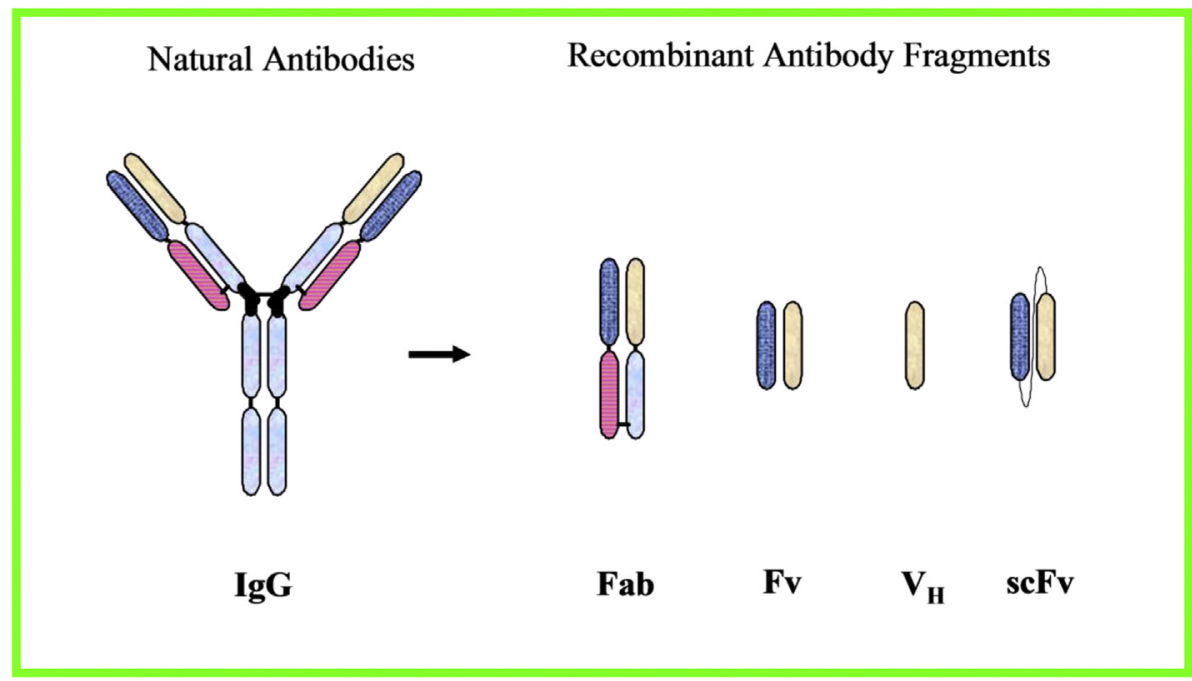

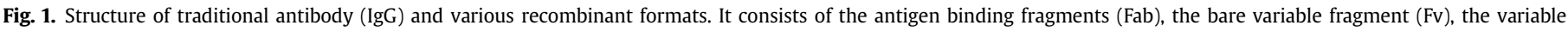
domain of heavy chain $\left(\mathrm{V}_{\mathrm{H}}\right)$ and the single chain variable fragment (scFv). (Modified from Ref. [50] with permission. Copyright $\odot$ 2003, Springer-Verlag).

Furthermore, recombinant antibodies can tolerate a range of conditions in solutions, such as acidic or basic $\mathrm{pH}$, high levels of heavy metal ions, organic solvents at concentrations over $10 \%$, all of which would denature conventional antibodies [47]. The robust nature of recombinant antibodies greatly broadens their application in immunoassays for EOCs analysis, because there might be some EOCs in industrial waste waters containing high concentration of heavy metals or organic wastes.

Some recombinant antibodies for EOCs have been manufactured that showed a remarkable range in characteristics. Kerrm et al. obtained a soluble Fab fragment against picloram (4-amino-3, 5, 6trichloro-2-pyridinecarboxylic acid) that showed 34\% crossreactivity to the pyridine herbicide clopyralid [48]. Li et al. produced three scFv antibodies from a phage-display library of a hyperimmunized mouse against the organophosphate pesticide methamidophos, which displayed better binding properties than the corresponding Mab [49]. Other selected examples are shown in Table 2.

Recently another biological binder called a receptor protein was developed against low molecular weight compounds [57]. The pharmacological effects of some EOCs, especially some of antibiotics and pesticides, have been thoroughly studied. These drugs exert biological effects through binding to target protein. Interestingly, this kind of protein can recognize a family of compounds with similar structures, which could provide a new strategy for developing binders to EOCs. For example, $\beta$-lactam antibiotics act by covalently binding to transpeptidases, or penicillin binding proteins (PBPs), and inhibiting the synthesis of the peptidoglycan layer of bacterial cell walls. A recombinant penicillin-binding protein (PBP) $2 \mathrm{X}^{*}$ from Streptococcus pneumniae R6 that is expressed in $E$. coli BL21 (DE3) and purified with His Bind ${ }^{\circledR}$ Columns was developed, and the assay based on PBP2X could detect all $16 \beta$-lactams with a

Table 2

Selected examples of recombinant antibodies for EOCs.

\begin{tabular}{lll}
\hline Recombinant antibody fragment & Target & Ref \\
\hline scFv & Triazine herbicide & {$[51]$} \\
scFv & Bisphenol A & {$[52]$} \\
Fab & 2,4-Dichlorophenoxyacetic acid & {$[53]$} \\
scFv & Picloram & {$[54]$} \\
ScFv & Chlorpyrifos-ethyl & {$[55]$} \\
scFv & Chlorpyrifos & {$[56]$} \\
\hline
\end{tabular}

limit of detection (LOD) in the range of $0.1-810 \mathrm{ng} / \mathrm{mL}$ [58]. In addition to antibiotics, organophosphates (OP) have been widely used to kill insects and animals through inhibiting acetyl cholinesterase by forming stable covalent intermediates. AlbaredaSirvent et al. developed a biosensor based on enzyme (AChE and $\mathrm{BChE}$ ) to detect paraoxon and carbofuran with a LOD of 0.165 and $0.047 \mathrm{ng} / \mathrm{mL}$, respectively [59]. However, because the toxicological mechanisms of some EOCs are not yet clear, it is difficult to produce a corresponding targeting protein. With increasing discoveries of the toxicological mechanisms of EOCs, we believe it will be possible to find the receptor proteins against EOCs and use these proteins in analytical methods.

\section{Immunochemical technique}

EOCs usually occur in environmental waters at very low concentrations accompanied by various matrices, thus analytical methods with enough sensitivity and selectivity are required. With the help of suitable antibodies, or other antibody-like binders, effective immunoanalytical approaches with high sensitivity, selectivity and simple (or without any) sample pre-treatment could be developed. Among them, ELISA and TRFIA are considered as reliable high-throughput immunoassays, while the immunosensor is a sensitive approach to quickly measure signal with simple equipment and suitable for on-site analysis of EOCs in water samples [8].

\subsection{ELISA}

ELISA was first applied to environmental chemicals determination in 1971 by Ercegovich [45]. It is now one of the most effective tools for monitoring EOCs in water by measuring changes in color or emission of light. ELISAs can be classified into direct and indirect competitive immunoassays. In the direct format, targets (unlabeled antigens) and labeled antigens are competitively recognized by immobilized antibodies, and signals are measured directly. The indirect assay is a more sophisticated procedure in which antibodies competitively capture dissolved targets and immobilized antigens. After the washing step, the labeled secondary antibodies bond to the corresponding antibodies. Signals can be obtained after incubation and another washing procedure [76]. Generally, indirect assays have better sensitivity and higher tolerance to sample 
matrices. The indirect mode was regarded as a suitable method for the detection of small molecular compounds in environmental water samples. As a result, ELISA has been the most popular immunoassay in the past decades for EOC determination in aquatic environments because of its low cost and simple procedure [11,12]. Assays based on traditional antibodies for EOCs are outlined in Table 3, and selected examples with receptor proteins and recombinant antibodies are shown in Table 4.

The selectivity and the sensitivity of ELISA are determined by antigen-antibody interaction. At the competitive reaction step, some matrices such as organic solvents [66,77-79] and other environmental factors [80] may interfere with the immunoreaction. To detect trace EOCs in aquatic environments, assays with more sensitive than ELISA have to be applied.

\subsection{TRFIA}

TRFIA is an ultrasensitive technology based on the unique fluorescence properties of the lanthanide ions such as europium $\left(\mathrm{Eu}^{3+}\right)$, samarium $\left(\mathrm{Sm}^{3+}\right)$, terbium $\left(\mathrm{Tb}^{3+}\right)$, gadolinium $\left(\mathrm{Gd}^{3+}\right)$ and

Table 3

Selected examples of ELISA for EOCs based on traditional antibodies.

\begin{tabular}{|c|c|c|c|c|}
\hline Class & EOC & Sample & Detection limit & Ref \\
\hline \multirow[t]{8}{*}{ Pharmaceutic-als } & $\begin{array}{l}\text { Carbamazepine, } \\
\text { caffeine cetirizine }\end{array}$ & Water & $0.025 \mathrm{ng} / \mathrm{mL}$ & {$[60]$} \\
\hline & Sulfamethoxazole & Waste water & $0.001 \mathrm{ng} / \mathrm{mL}$ & {$[61]$} \\
\hline & E2 and EE2 & Aqueous sample & $0.02,0.03 \mathrm{ng} / \mathrm{L}$ & {$[62]$} \\
\hline & Carbamazepine & Water & $0.03 \mathrm{ng} / \mathrm{mL}$ & [13] \\
\hline & Tylosin & Waste water & $0.03 \mathrm{ng} / \mathrm{L}$ & {$[42]$} \\
\hline & Sulfonamides & Water & $0.04 \mathrm{ng} / \mathrm{L}$ & [63] \\
\hline & Indomethacin & Water & $0.01 \mathrm{ng} / \mathrm{mL}$ & {$[26]$} \\
\hline & Nitrofurantoin & Water & $0.2 \mathrm{ng} / \mathrm{mL}$ & [28] \\
\hline \multirow[t]{8}{*}{ Pesticides } & Carbofuran & $\begin{array}{l}\text { Water, } \\
\text { soil, vegetables }\end{array}$ & $0.11 \mathrm{ng} / \mathrm{mL}$ & {$[32]$} \\
\hline & $\begin{array}{l}\text { Diuron, monuron, } \\
\text { linuron }\end{array}$ & Water & $0.04-0.08 \mu \mathrm{g} / \mathrm{L}$ & [64] \\
\hline & Malathion & Water & $0.11 \mathrm{ng} / \mathrm{mL}$ & [10] \\
\hline & Carbofuran & Water & $0.27 \mu \mathrm{g} / \mathrm{L}$ & {$[65]$} \\
\hline & Triazophos & Water, soil & $0.02 \mu \mathrm{g} / \mathrm{L}$ & {$[66]$} \\
\hline & Chlorpyrifos & Water & $0.1 \mu \mathrm{g} / \mathrm{L}$ & [37] \\
\hline & Malathion & Water & $0.11 \mathrm{ng} / \mathrm{mL}$ & [10] \\
\hline & Deltamethrin & Water & $1.1 \pm 0.5 \mu \mathrm{g} / \mathrm{L}$ & [67] \\
\hline \multirow{7}{*}{$\begin{array}{l}\text { Industrial } \\
\text { additives }\end{array}$} & Bisphenol A. & water & $0.1 \mathrm{ng} / \mathrm{mL}$ & [39] \\
\hline & Diethyl phthalate & Water & $0.096 \mathrm{ng} / \mathrm{mL}$ & [68] \\
\hline & $\begin{array}{l}\text { Di-(2-ethylhexyl) } \\
\text { phthalate }\end{array}$ & Human urine & $0.56 \mathrm{ng} / \mathrm{mL}$ & [38] \\
\hline & $\begin{array}{l}\text { Caffeine and } \\
\text { cotinine }\end{array}$ & Water & $\begin{array}{l}0.135, \\
0.047 \mathrm{ng} / \mathrm{mL}\end{array}$ & [69] \\
\hline & $\begin{array}{l}\text { Dimethyl } \\
\text { Phthalate }\end{array}$ & Water & $0.02 \mathrm{ng} / \mathrm{mL}$ & {$[40]$} \\
\hline & Alkylphenols & Soils and waters & $0.001 \mathrm{ng} / \mathrm{mL}$ & {$[70]$} \\
\hline & Nonylphenol (NP) & Water & $10 \mathrm{ng} / \mathrm{mL}$ & [41] \\
\hline \multirow{2}{*}{$\begin{array}{l}\text { Personal care } \\
\text { products }\end{array}$} & Triclocarban & Body fluids & $0.13 \mathrm{ng} / \mathrm{mL}$ & [71] \\
\hline & Triclosan & Water & $0.03 \mathrm{ng} / \mathrm{L}$ & {$[42]$} \\
\hline
\end{tabular}

Table 4

Selected examples of ELISA for EOCs based on antibody-like binders.

\begin{tabular}{llll}
\hline Binder & EOC & Detection limit & Ref \\
\hline ScFv & Cyclohexanedione & - & {$[72]$} \\
ScFv & Organophosphorus pesticides & - & {$[56]$} \\
Fab & Picloram & $10 \mathrm{ng} / \mathrm{mL}$ & {$[48]$} \\
ScFv & Cotinine & $31 \mathrm{pg} / \mathrm{mL}$ & {$[73]$} \\
ScFv & Methamidophos & $0.04-0.26 \mathrm{ng} / \mathrm{mL}$ & {$[49]$} \\
ScFv & Clenbuterol & $0.78 \mathrm{ng} / \mathrm{mL}\left(\mathrm{IC}_{50}\right)$ & {$[74]$} \\
ScFv & Simetryn & $1.1-70 \mathrm{ng} / \mathrm{mL}$ & {$[51]$} \\
Receptors & $\beta$-lactams & $0.1-810 \mathrm{ng} / \mathrm{mL}$ & {$[58]$} \\
Receptors & Sulphonamides & $1.6-59 \mathrm{ng} / \mathrm{mL}$ & {$[75]$} \\
\hline
\end{tabular}

dysprosium $\left(\mathrm{Dy}^{3+}\right)$, which provide narrow-band emission lines, long Stokes shifts, high quantum yields, and long decay lifetimes $[81,82]$. These advantages can reduce background fluorescence inherent in the sample matrix [45] or scattering from nearby optics [83], and high sensitivity.

TRFIA has played an important role in determination of trace EOCs in water. It was reported that the detection limits of TRFIA against triazine herbicides was as low as $0.1 \mu \mathrm{g} / \mathrm{L}$ [84]. Using generic ScFv fragments, Korpimaki et al. established a TRFIA method for simultaneous determination of 18 different sulfonamides in meat, milk, and serum samples [85]. Our group also developed a TRFIA approach with commercially available Mab labeled $\mathrm{Eu}^{3+}$ chelates for trace analysis of sulfamethazine (SMZ), sulfamethoxazole (SMX) and sulfadiazine (SDZ) in environmental waters, and the results indicated satisfactory recoveries (accuracy) and good repeatability, as well as lower detection limits than the corresponding ELISA methods [86].

We also developed a class-specific mAb and established a TRFIA method to detect the total concentration of twelve fluoroquinolones in environmental waters. More importantly, this was the first report on the use of immunoassay-based total concentration for direct evaluation of the environmental risk of a class of compounds (Fig. 2). Traditionally, for evaluating environmental exposure and risk of a class of compounds with potential additive toxicity, the total concentration of target compounds is determined by the sum of each individual compound concentration that is usually determined by SPE coupled with LC-MS/MS. Unlike the traditional LC-MS/MS approach that is expensive and timeconsuming, this TRFIA method is low-cost and efficient as it was performed without sample pre-treatment and consumed only microliters of samples [87].

Beyond TRFIA, radioimmunoassays (RIA) and chemiluminescence immunoassay $(\mathrm{CI})$ are high-throughput immunoassays with high sensitivity, but both of these methods are mainly used in medical diagnosis because the techniques need specialized equipment and special labeling reagents. At the same time, in contrast with these methods, TRFIA can meet the requirement of multi-targets analysis using different lanthanide ions as tracers.

\subsection{Superiority of high-throughput immunoassay for environmental samples}

In food analysis, especially the detection of antibiotics residues in milk and animal tissues, high-throughput immunoassays (including ELISA, TRFIA, RIA and $\mathrm{CI}$ ) are used as screening tools for large numbers of samples with LC-MS/MS or other chromatographic methods used for more quantitative results. In other words, immunoassays are just a kind of supplement for instrumental methods. But EOCs monitoring in environmental waters requires long-term investigation on the pattern, behavior or distribution and seasonal variation of these chemicals in an aquatic environment. The real trends which can be reflected only through the analysis of a great deal of samples. Therefore, high-throughput immunoassays that provide rapid answers at low cost are preferred, while expensive chromatographic methods with sophisticated pretreatment are unimaginable. It is noteworthy that although TRFIA is regarded as a more sensitive method than conventional ELISA, the cost of lanthanide ions chelates used in TRFIA system is much higher than that in ELISA. On the other hand, ELISA could meet the most of requirements for EOCs detections due to the high sensitivity of antibodies. As a consequence, ELISA was widely reported instead of TRFIA. Byer et al. [88] holds the similar view that ELISA could provide a cost-effective alternative for improving temporal and/or spatial monitoring after they measured a total of 533 samples from more than 100 sites in Ontario, and they also think ELISA has great 


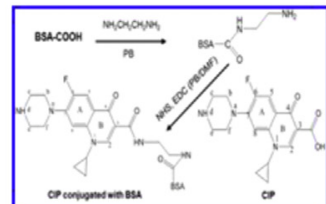

\section{BALB/c mice} $\underset{\text { Immunization }}{\longrightarrow}$ (Mab, class-specific)

FQ antigen synthesis

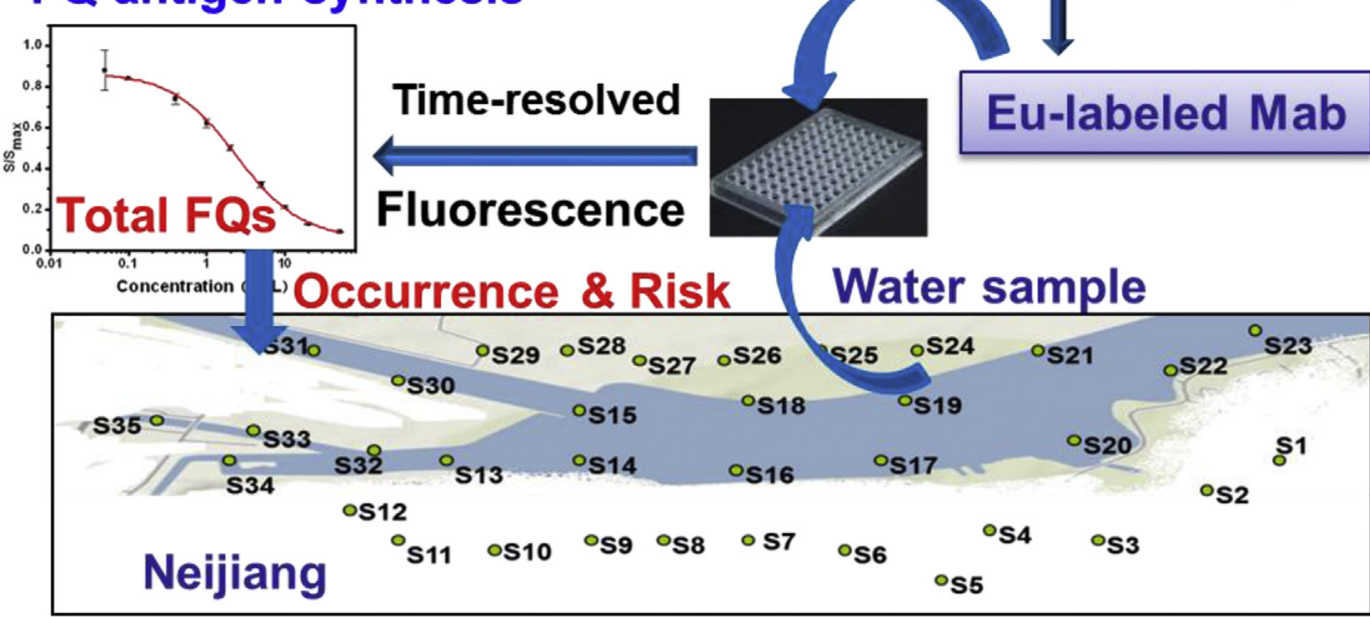

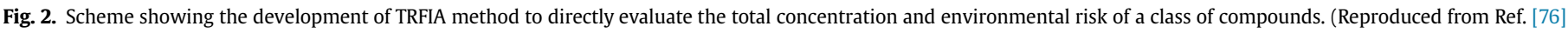
with permission. Copyright @ 2010 , American Chemical Society).

potential applications because of the little to no sample pretreatment and rapidness. In the 2004 National Atrazine Occurrence Monitoring Program that was conducted under the joint sponsorship of the American Water Works Association's (AWWA) Water Industry Technical Action Fund (WITAF) program and the American Water Works Association Research Foundation (AwwaRF), highthroughput immunoassay (ELISA kits) were selected as the most suitable method to investigate a pesticide in waters, and they also thought that frequent monitoring was costly and time-consuming with GC/MS in contrast with immunoassay [80].

\subsection{Immunosensor}

An immunosensor is an analytical device which incorporates antibodies to be responsible for recognizing the targets and contains a transducer to convert the recognition into a measurable signal for the rapid determination of analytes. An immunosensor is one type of biosensors that is based on biological or synthetic binders. The operating principle of immunosensors is that changes would begin in the physicochemical parameters of the detecting system when specific immunoreactions proportional to the concentration of targets happen, resulting in a measurable optical or electrical signal [89]. As an integrated device, immunosensors omit some complex steps such as washing and regent addition steps, and they could be automated to perform analysis without sample manipulation and in a miniaturized portable device [90].

In EOC analysis, immunosensors are indispensable supplements of high-throughput immunoassays and chromatographic methods. Immunosensors can achieve on-site analysis without the use of lab instruments. Concentrations of EOC contaminants in water could be obtained quickly without collection of a large number of water samples far away from the laboratory.

Many transducers have been used in immunosensors include piezoelectric, micromechanical, electrochemical and optical sensors. The latter two immunosensors are the most popular in EOC monitoring.
Optical immunosensors (shown in Fig. 3) exploit various optical properties based on fluorescence, light absorption, chemilumenescence or surface-plasmon resonance [91]. The reaction of an antibody capturing its corresponding antigens results in changes of absorption or emission of light in that can be measured [8]. In recent years optical immunosensors have found applications in detecting pollutants because the availability and range of optical transducers have grown, benefitting mainly from the development of fiber optic technology [92].

Electrochemical immunosensors (Fig. 4) measure signal responses through variation in ion concentration or electron density caused by antibody-antigen interaction. These sensors have high sensitivity, compatibility with modern microfabrication technologies and high tolerance [93], and have high tolerance against quenching, sample turbidity and interference from absorbing and fluorescing compounds (popular in biological samples) [94].

In order to increase signal to noise ratios and decrease time of response of immunosensors, nanoparticles have been introduced into this detection system and their main roles lie in: (i) improving the performance of immunosensors due to their unique physical and chemical properties; (ii) enlarging the surface area available to bind more antibodies and thus amplify the signals. In addition, for optical immunosensors, the application of nanoparticles contributes to the exploration of new optical phenomena and promotes the optical properties of materials [95]. As to electrochemical immunosensors, nanoparticles provide the ability to enhance selectivity and reduce the background current $[90,96]$. A disposable electrochemical immunosensor for the detection of diuron with laser ablated gold electrodes fabricated on polystyrene substrate was reported with a detection limit of $1 \mathrm{ng} / \mathrm{L}$ [97]. We have designed a novel electrochemical immunosensor for ultra-sensitive detection of dibutyl phthalate (DBP) in environmental waters, and the amplification of electrochemical signals was realized by the increase of the steric hindrance and electrostatic repulsion, which was achieved by optimizing the size of the gold nanoparticles and signal was amplified using AuNPs enlargement through NADH- 


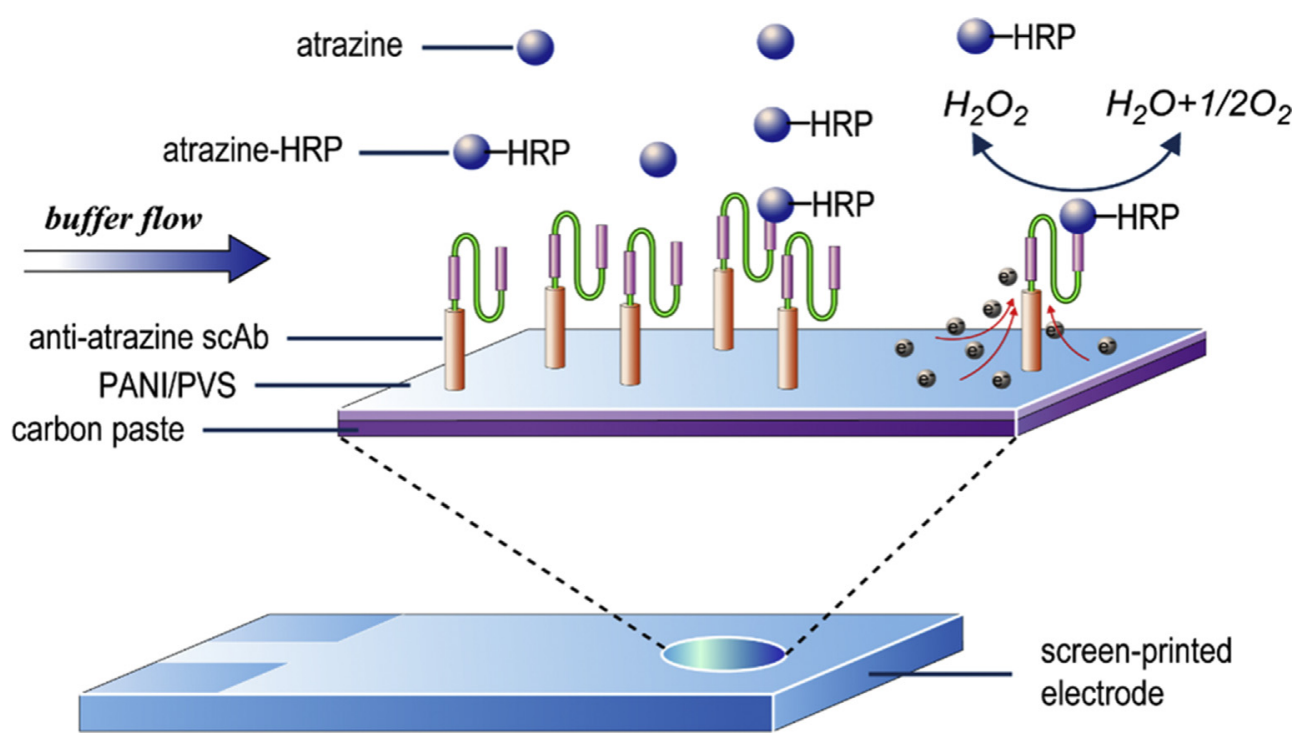

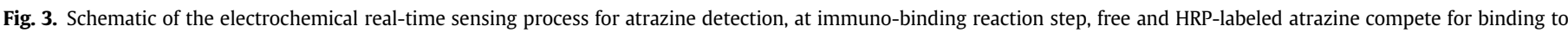
immobilized antibodies (scAb fragments). (Reproduced from Refs. [94,98] with permission. Copyright @ 2008 Elsevier B.V.).

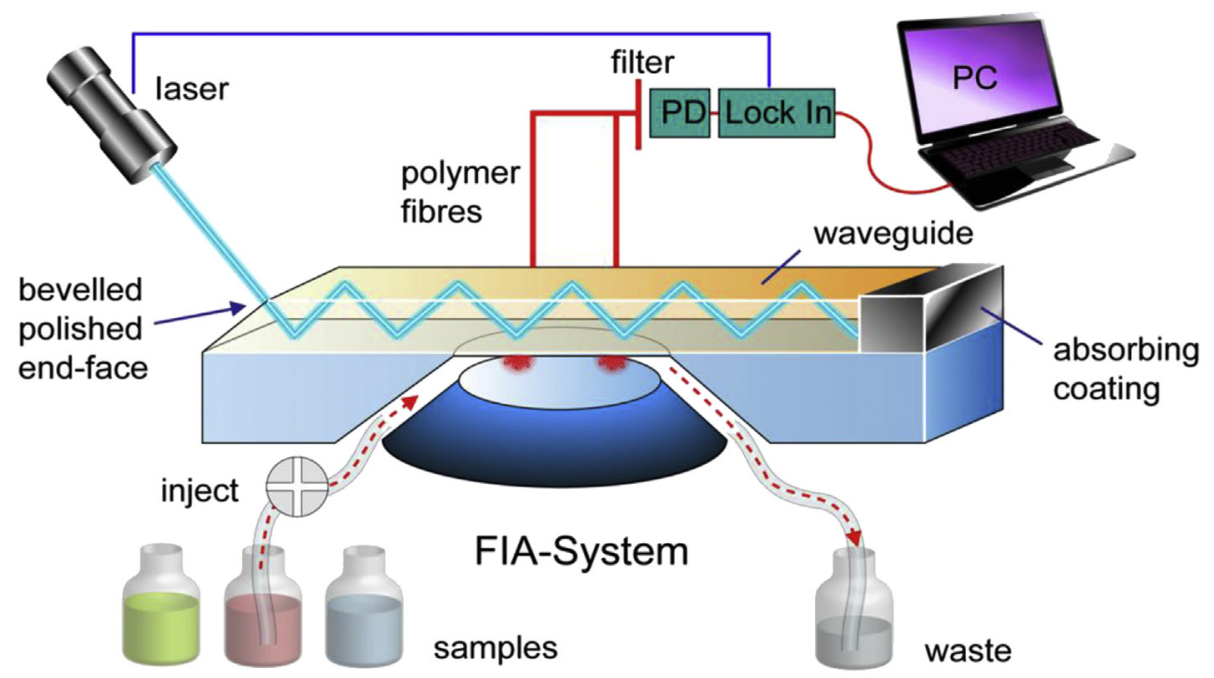

Fig. 4. General scheme of optical immunosensor with FIA system. (Reproduced from Ref. [99] with permission. Copyright @ 2001 Elsevier Science B.V.).

promoted catalytic precipitation. The approach showed one order of magnitude higher sensitivity than the conventional ELSIA that was carried out with same antibody (under revision). Table 5 lists optical immunosensors that have been used to sense EOCs in environmental waters.

\section{Perspectives and conclusions}

For EOC analysis, the first thing that analysts should take into account is cost, so among all kinds of biological and synthetic binders, pAbs are the first choice in immunoassays because of their low cost and simple production procedure. Being reliable, effective and well-established, traditional antibody production would still play an important role in immunochemical techniques. At the same time, in order to achieve multi-analyte determinations for EOCs, computer-assisted molecular modeling techniques are very useful in hapten-aided design for broadspectrum antibodies. However, with the increasing development and maturity of other biological binders, such as aptamers, receptor and recombinant antibodies, the cost of production will decrease gradually, allowing them to have great potential in applications for detecting EOCs in waters instead of traditional antibodies because of their unique properties.

Table 5

Selected examples of sensing EOCs in waters by immunosensor.

\begin{tabular}{lllll}
\hline Organic containment & Sample & Detector & Detection limit & Ref \\
\hline Pesticides & Water & Fluorescence & $0.03-4.23 \mu \mathrm{g} / \mathrm{L}$ & {$[100]$} \\
Estrone & Water & Fluorescence & $<0.20 \mathrm{ng} / \mathrm{L}$ & {$[101]$} \\
Propanil & Water & Fluorescence & $0.6 \mathrm{ng} / \mathrm{L}$ & {$[102]$} \\
Bisphenol A & Water & Fluorescence & $0.014 \mu \mathrm{g} / \mathrm{L}$ & {$[103]$} \\
TNT & Water & Fluorescence & $0.05 \mu \mathrm{g} / \mathrm{L}$ & {$[104]$} \\
Antibiotics & Water & Fluorescence & $2.4-6 \mathrm{ng} / \mathrm{mL}$ & {$[105]$} \\
17 Beta-estradiol & Water & Fluorescence & $0.6 \mathrm{ng} / \mathrm{mL}$ & {$[106]$} \\
Bisphenol A & Water & Surface plasmon & $0.08 \mathrm{ng} / \mathrm{L}$ & {$[107]$} \\
& & resonance & & \\
Azinphos-methyl & Water & Amperometric & $0.6 \mathrm{nmol} / \mathrm{L}$ & {$[108]$} \\
Sulfamethoxazole & Soil, water & Piezoelectric quartz & $0.15 \mathrm{ng} / \mathrm{L}$ & {$[109]$} \\
\hline
\end{tabular}


In methodology, compared to the cumbersome, sophisticated and expensive chromatographic methods, we believe that highthroughput immunoassays show more advantages for studying the occurrence, temporal and spatial distribution, pattern and behavior of EOCs, and long-term influences caused by the organic pollutants because they are simple to operate, do not always require sample pretreatment, and possess high throughput. Furthermore, the real negative effects to the aquatic ecosystem by EOCs could be evaluated after large numbers of samples analysis with immunoassays, which is difficult to be performed by instrument methods in a short time.

In addition, considering that EOCs could remain in denatured aquatic environments (high concentrations of heavy metals, organic solvents, salt ions), for instance, in industrial waste waters, molecularly imprinted polymers (MIPs) and recombinant antibody formats might be good choices because they possess high tolerance against various matrix effects, and biosensors based on these binders are able to quickly measure the concentration of EOCs in the waters. The sensitivity is the most important metric for all immunosensors, and the current trend for immunosensors is to achieve better sensitivity via nanomaterial properties. In the future nanoparticles may be used in immunosensor detection systems to improve their performance.

In summary, with developments in traditional antibodies, recombinant antibodies and other new binders, various effective, smart, and cheap immunochemical methods have been developed for the analysis of EOCs in aquatic environments. Using simple and suitable approaches, the pollution status of EOCs in environmental waters can be measured, which will provide important background data for risk assessment and contamination control of these containments in the aquatic environment.

\section{Acknowledgment}

This work was jointly supported the Strategic Priority Research Program of the Chinese Academy of Sciences (XDB14020101), the National Natural Science Foundation of China (Grant 21577051, 31502118, 21321004).

\section{References}

[1] M.J. Focazio, D.W. Kolpin, K.K. Barnes, E.T. Furlong, M.T. Meyer, S.D. Zaugg L.B. Barber, M.E. Thurman, A national reconnaissance for pharmaceuticals and other organic wastewater contaminants in the United States - II) Untreated drinking water sources, Sci. Total Environ. 402 (2008) 201-216.

[2] M. Petrovic, E. Eljarrat, M.J.L. de Alda, D. Barcelo, Endocrine disrupting compounds and other emerging contaminants in the environment: a survey on new monitoring strategies and occurrence data, Anal. Bioanal. Chem. 378 (2004) 549-562.

[3] D.J. Lapworth, N. Baran, M.E. Stuart, R.S. Ward, Emerging organic contaminants in groundwater: a review of sources, fate and occurrence, Environ. Pollut. 163 (2012) 287-303.

[4] C.Y. Hao, X.M. Zhao, S. Tabe, P. Yang, Optimization of a multiresidual method for the determination of waterborne emerging organic pollutants using solid-phase extraction and liquid chromatography/tandem mass spectrometry and isotope dilution mass spectrometry, Environ. Sci. Technol. 42 (2008) 4068-4075.

[5] J.Y. Pailler, A. Krein, L. Pfister, L. Hoffmann, C. Guignard, Solid phase extraction coupled to liquid chromatography-tandem mass spectrometry analysis of sulfonamides, tetracyclines, analgesics and hormones in surface water and wastewater in Luxembourg, Sci. Total Environ. 407 (2009) 4736-4743.

[6] D. Stajnbaher, L. Zupancic-Kralj, Multiresidue method for determination of 90 pesticides in fresh fruits and vegetables using solid-phase extraction and gas chromatography-mass spectrometry, J. Chromatogr. A 1015 (2003) 185-198.

[7] S. Weigel, R. Kallenborn, H. Huhnerfuss, Simultaneous solid-phase extraction of acidic, neutral and basic pharmaceuticals from aqueous samples at ambient (neutral) $\mathrm{pH}$ and their determination by gas chromatography-mass spectrometry, J. Chromatogr. A 1023 (2004) 183-195.

[8] C.R. Suri, R. Boro, Y. Nangia, S. Gandhi, P. Sharma, N. Wangoo, K. Rajesh G.S. Shekhawat, Immunoanalytical techniques for analyzing pesticides in the environment, Trac-Trends Anal. Chem. 28 (2009) 29-39.
[9] Z.L. Xu, D.P. Zeng, J.Y. Yang, Y.D. Shen, R.C. Beier, H.T. Lei, H. Wang, Y.M. Sun, Monoclonal antibody-based broad-specificity immunoassay for monitoring organophosphorus pesticides in environmental water samples, J. Environ. Monit. 13 (2011) 3040-3048.

[10] E.M. Brun, M. Garces-Garcia, M.J. Banuls, J.A. Gabaldon, R. Puchades, A. Maquieira, Evaluation of a novel malathion immunoassay for groundwater and surface water analysis, Environ. Sci. Technol. 39 (2005) 2786-2794.

[11] M. Farre, L. Kantiani, D. Barcelo, Advances in immunochemical technologies for analysis of organic pollutants in the environment, Trac Trends Anal. Chem. 26 (2007) 1100-1112.

[12] W.W. Buchberger, Novel analytical procedures for screening of drug residues in water, waste water, sediment and sludge, Anal. Chim. Acta 593 (2007) 129-139.

[13] V. Calisto, A. Bahlmann, R.J. Schneider, V.I. Esteves, Application of an ELISA to the quantification of carbamazepine in ground, surface and wastewaters and validation with LC-MS/MS, Chemosphere 84 (2011) 1708-1715.

[14] S.O. Obare, C. De, W. Guo, T.L. Haywood, T.A. Samuels, C.P. Adams, N.O. Masika, D.H. Murray, G.A. Anderson, K. Campbell, K. Fletcher, Fluorescent chemosensors for toxic organophosphorus pesticides: a review,, Sensors 10 (2010) 7018-7043.

[15] I. Surugiu, J. Svitel, L. Ye, K. Haupt, B. Danielsson, Development of a flow injection capillary chemiluminescent ELISA using an imprinted polymer instead of the antibody, Anal. Chem. 73 (2001) 4388-4392.

[16] L.X. Zhao, L. Sun, X.G. Chu, Chemiluminescence immunoassay, Trac Trends Anal. Chem. 28 (2009) 404-415.

[17] T. Fodey, P. Leonard, J. O'Mahony, R. O'Kennedy, M. Danaher, Developments in the production of biological and synthetic binders for immunoassay and sensor-based detection of small molecules, Trac Trends Anal. Chem. 30 (2011) 254-269.

[18] Z.H. Wang, M.X. Liu, W.M. Shi, C.L. Li, S.X. Zhang, J.Z. Shen, New haptens and antibodies for ractopamine, Food Chem. 183 (2015) 111-114.

[19] Z.L. Xu, Y.D. Shen, W.X. Zheng, R.C. Beier, G.M. Xie, J.X. Dong, J.Y. Yang, H. Wang, H.T. Lei, Z.G. She, Y.M. Sun, Broad-specificity immunoassay for O,Odiethyl organophosphorus pesticides: application of molecular modeling to improve assay sensitivity and study antibody recognition, Anal. Chem. 82 (2010) 9314-9321.

[20] Z.H. Wang, Y. Zhu, S.Y. Ding, F.Y. He, R.C. Beier, J.C. Li, H.Y. Jiang, C.W. Feng, Y.P. Wan, S.X. Zhang, Z.P. Kai, X.L. Yang, J.Z. Shen, Development of a monoclonal antibody-based broad-specificity ELISA for fluoroquinolone antibiotics in foods and molecular modeling studies of cross-reactive compounds, Anal. Chem. 79 (2007) 4471-4483.

[21] J. Adrian, H. Font, J.M. Diserens, F. Sanchez-Baeza, M.P. Marco, Generation of broad specificity antibodies for sulfonamide antibiotics and development of an enzyme-linked immunosorbent assay (ELISA) for the analysis of milk samples, J. Agric. Food Chem. 57 (2009) 385-394.

[22] W. Haasnoot, G. Cazemier, J. Du Pre, A. Kemmers-Voncken, M. BienenmannPloum, R. Verheijen, Sulphonamide antibodies: from specific polyclonals to generic monoclonals, Food Agric. Immunol. 12 (2000) 15-30.

[23] G.A. Posthuma-Trumpie, J. Korf, A. van Amerongen, Development of a competitive lateral flow immunoassay for progesterone: influence of coating conjugates and buffer components, Anal. Bioanal. Chem. 392 (2008) 1215-1223.

[24] M. Kato, Y. Ihara, E. Nakata, M. Miyazawa, M. Sasaki, T. Kodaira, H. Nakazawa, Development of enrofloxacin ELISA using a monoclonal antibody tolerating an organic solvent with broad cross-reactivity to other newquinolones, Food Agric. Immunol. 18 (2007) 179-187.

[25] H.L. Xie, W. Ma, L.Q. Liu, W. Chen, C.F. Peng, C.L. Xu, L.B. Wang, Development and validation of an immunochromatographic assay for rapid multi-residues detection of cephems in milk, Anal. Chim. Acta 634 (2009) 129-133.

[26] S.M. Huo, H. Yang, A.P. Deng, Development and validation of a highly sensitive ELISA for the determination of pharmaceutical indomethacin in water samples, Talanta 73 (2007) 380-386.

[27] Y.L. Zhang, S.X. Lu, W. Liu, C.B. Zhao, R.M. Xi, Preparation of anti-tetracycline antibodies and development of an indirect heterologous competitive enzyme-linked immunosorbent assay to detect residues of tetracycline in milk, J. Agric. Food Chem. 55 (2007) 211-218.

[28] W. Liu, C.B. Zhao, Y.L. Zhang, S.X. Lu, J.T. Liu, R. Xi, Preparation of polyclonal antibodies to a derivative of 1-aminohydantoin (AHD) and development of an indirect competitive ELISA for the detection of nitrofurantoin residue in water, J. Agric. Food Chem. 55 (2007) 6829-6834.

[29] J. Tschmelak, G. Proll, G. Gauglitz, Sub-nanogram per litre detection of the emerging contaminant progesterone with a fully automated immunosensor based on evanescent field techniques, Anal. Chim. Acta 519 (2004) $143-146$.

[30] S. Fang, B. Zhang, K.W. Ren, M.M. Cao, H.Y. Shi, M.H. Wang, Development of a sensitive indirect competitive enzyme-linked immunosorbent assay (icELISA) based on the monoclonal antibody for the detection of the imidaclothiz residue, J. Agric. Food Chem. 59 (2011) 1594-1597.

[31] Y. Kong, Q. Zhang, W. Zhang, S.J. Gee, P.W. Li, Development of a monoclonal antibody-based enzyme immunoassay for the pyrethroid insecticide deltamethrin, J. Agric. Food Chem. 58 (2010) 8189-8195.

[32] J.Y. Yang, H. Wang, Y.M. Jiang, Y.M. Sun, K.T. Pan, H.T. Lei, Q. Wu, Y.D. Shen, Z.L. Xiao, Z.L. Xu, Development of an enzyme-linked immuno-sorbent assay (ELISA) method for carbofuran residues, Molecules 13 (2008) 871-881. 
[33] M. Nakata, A. Fukushima, H. Ohkawa, A monoclonal antibody-based ELISA for the analysis of the insecticide flucythrinate in environmental and crop samples,, Pest Manag. Sci. 57 (2001) 269-277.

[34] A. Abad, M.J. Moreno, A. Montoya, Hapten synthesis and production of monoclonal antibodies to the N-methylcarbamate pesticide methiocarb, J. Agric. Food Chem. 46 (1998) 2417-2426.

[35] J.K. Lee, S.H. Park, E.Y. Lee, Y.J. Kim, K.S. Kyung, Development of an enzymelinked immunosorbent assay for the detection of the fungicide fenarimol, J. Agric. Food Chem. 52 (2004) 7206-7213.

[36] J.K. Lee, K.C. Ahn, O.S. Park, S.Y. Kang, B.D. Hammock, Development of an ELISA for the detection of the residues of the insecticide imidacloprid in agricultural and environmental samples, J. Agric. Food Chem. 49 (2001) 2159-2167.

[37] J.J. Sullivan, Y.G. Chen, K.S. Goh, Performance assessment and validation of a paramagnetic particle-based enzyme-linked immunosorbent assay for chlorpyrifos in agricultural runoff waters, J. Agric. Food Chem. 55 (2007) 6407-6416.

[38] X.L. Feng, S.Y. Lu, D. Liu, L. Li, X.Z. Wu, J. Song, P. Hu, Y.S. Li, F. Tang, Z.H. Li, G.M. Wang, Y. Zhou, Z.S. Liu, H.L. Ren, Direct competitive immunosorbent assay for detection of MEHP in human urine, Chemosphere 92 (2013) $150-155$.

[39] M.P. Zhao, Y.Z. Li, Z.Q. Guo, X.X. Zhang, W.B. Chang, A new competitive enzyme-linked immunosorbent assay (ELISA) for determination of estrogenic bisphenols,, Talanta 57 (2002) 1205-1210.

[40] M.C. Zhang, S.H. Liu, H.S. Zhuang, Y.R. Hu, Determination of dimethyl phthalate in environment water samples by a highly sensitive indirect competitive ELISA, Appl. Biochem. Biotechnol. 166 (2012) 436-445.

[41] A.A. Mart'ianov, A.V. Zherdev, S.A. Eremin, B.B. Dzantiev, Preparation of antibodies and development of enzyme-linked immunosorbent assay for nonylphenol, Int. J. Environ. An. Ch 84 (2004) 965-978.

[42] E.M. Brun, E. Bonet, R. Puchades, A. Maquieira, Selective enzyme-linked Immunosorbent assay for triclosan. Application to wastewater treatment plant effluents, Environ. Sci. Technol. 42 (2008) 1665-1672.

[43] S.T. Wang, W.J. Gui, Y.R. Guo, G.N. Zhu, Preparation of a multi-hapten antigen and broad specificity polyclonal antibodies for a multiple pesticide immunoassay, Anal. Chim. Acta 587 (2007) 287-292.

[44] Z. Wang, T. Mi, R.C. Beier, H. Zhang, Y. Sheng, W. Shi, S. Zhang, J. Shen, Hapten synthesis, monoclonal antibody production and development of a competitive indirect enzyme-linked immunosorbent assay for erythromycin in milk, Food Chem. 171 (2015) 98-107.

[45] K.Y.F. Yau, H. Lee, J.C. Hall, Emerging trends in the synthesis and improvement of hapten-specific recombinant antibodies, Biotechnol. Adv. 21 (2003) 599-637.

[46] J. Brichta, M. Hnilova, T. Viskovic, Generation of hapten-specific recombinant antibodies: antibody phage display technology: a review, Vet. Med. 50 (2005) 231-252.

[47] G. Strachan, J.A. Whyte, P.M. Molloy, G.I. Paton, A.J.R. Porter, Development of robust, environmental, immunoassay formats for the quantification of pesticides in soil, Environ. Sci. Technol. 34 (2000) 1603-1608.

[48] N.L.T. Kerrm, Y.F. Yau, Jack T. Trevors, Hung Lee, J. Christopher Hall, Bacterial expression and characterization of a picloram-specific recombinant fab for residue analysis, J. Agric. Food Chem. 46 (1998) 4457-4463.

[49] T.J. Li, Q. Zhang, Y. Liu, D.F. Chen, B.S. Hu, D.A. Blake, F.Q. Liu, Production of recombinant ScFv antibodies against methamidophos from a phage-display library of a hyperimmunized mouse, J. Agric. Food Chem. 54 (2006) 9085-9091.

[50] K. Kramer, B. Hock, Recombinant antibodies for environmental analysis, Anal. Bioanal. Chem. 377 (2003) 417-426.

[51] K. Nishi, M. Ishiuchi, K. Morimune, H. Ohkawa, Molecular and immunochemical characteristics of monoclonal and recombinant antibodies selective for the triazine herbicide simetryn and application to environmental analysis, J. Agric. Food Chem. 53 (2005) 5096-5104.

[52] K. Nishi, M. Takai, K. Morimune, H. Ohkawa, Molecular and immunochemical characteristics of monoclonal and recombinant antibodies specific to bisphenol A, Biosci. Biotechnol. Biochem. 67 (2003) 1358-1367.

[53] M.M. Melanie Gerdes, Friedrich Spener, Development of a displacement immunoassay by exploiting cross-reactivity of a monoclonal antibody, Anal. Biochem. 252 (1997) 198-204.

[54] N.L. Tout, K.Y.F. Yau, J.T. Trevors, H. Lee, J.C. Hall, Synthesis of ligand-specific phage-display ScFv against the herbicide picloram by direct cloning from hyperimmunized mouse, J. Agric. Food Chem. 49 (2001) 3628-3637.

[55] M.J.C. Alcocer, C. Doyen, H.A. Lee, M.R.A. Morgan, Properties of polyclonal, monoclonal, and recombinant antibodies recognizing the organophosphorus pesticide chlorpyrifos-ethyl, J. Agric. Food Chem. 48 (2000) 4053-4059.

[56] M.J.C. Alcocer, C. Doyen, H.A. Lee, M.R.A. Morgan, Functional scFv antibody sequences against the organophosphorus pesticide chlorpyrifos, J. Agric. Food Chem. 48 (2000) 335-337.

[57] J. Lamar, M. Petz, Development of a receptor-based microplate assay for the detection of beta-lactam antibiotics in different food matrices, Anal. Chim. Acta 586 (2007) 296-303.

[58] K. Zeng, J. Zhang, Y. Wang, Z.H. Wang, S.X. Zhang, C.M. Wu, J.Z. Shen, Development of a rapid multi-residue assay for detecting $\beta$-lactams using penicillin binding protein 2x*, Biomed. Environ. Sci. 26 (2013) 100-109.
[59] M. Albareda-Sirvent, A. Merkoçi, S. Alegret, Pesticide determination in tap water and juice samples using disposable amperometric biosensors made using thick-film technology, Anal. Chim. Acta 442 (2001) 35-44.

[60] A. Bahlmann, J.J. Carvalho, M.G. Weller, U. Panne, R.J. Schneider, Immunoassays as high-throughput tools: monitoring spatial and temporal variations of carbamazepine, caffeine and cetirizine in surface and wastewaters, Chemosphere 89 (2012) 1278-1286.

[61] N. Pastor-Navarro, E.M. Brun, E. Gallego-Iglesias, A. Maquieira, R. Puchades, Development of immunoassays to determinate sulfamethoxazole residues in wastewaters, J. Environ. Monit. 11 (2009) 1094-1100.

[62] C.P. Silva, D.L.D. Lima, R.J. Schneider, M. Otero, V.I. Esteves, Development of ELISA methodologies for the direct determination of 17 beta-estradiol and 17 alpha-ethinylestradiol in complex aqueous matrices, J. Environ. Manage 124 (2013) 121-127.

[63] W.L. Shelver, N.W. Shappell, M. Franek, F.R. Rubio, ELISA for sulfonamides and its application for screening in water contamination, J. Agric. Food Chem. 56 (2008) 6609-6615.

[64] P. Schneider, M.H. Goodrow, S.J. Gee, B.D. Hammock, A highly sensitive and rapid ELISA for the arylurea herbicides diurion, monuron, and linrion, J. Agric. Food Chem. 42 (1994) 413-422.

[65] C.Z. Liang, W.J. Gui, L. Zhao, Q. Qi, G.N. Zhu, Optimization of a direct competitive enzyme-linked immunoassay for carbofuran and application to water samples, Anal. Lett. 41 (2008) 1304-1317.

[66] C. Liang, R. Jin, W. Gui, G. Zhu, Enzyme-linked Immunosorbent assay based on a monoclonal antibody for the detection of the insecticide triazophos: assay optimization and application to environmental samples, Environ. Sci. Technol. 41 (2007) 6783-6788.

[67] H.J. Lee, G. Shan, T. Watanabe, D.W. Stoutamire, S.J. Gee, B.D. Hammock, Enzyme-linked immunosorbent assay for the pyrethroid deltamethrin, J. Agric. Food Chem. 50 (2002) 5526-5532.

[68] M.C. Zhang, Y. Cong, Y.L. Sheng, B.L. Liu, A direct competitive enzyme-linked immunosorbent assay by antibody coated for diethyl phthalate analysis, Anal. Biochem. 406 (2010) 24-28.

[69] S. Nicolardi, S. Herrera, M.J.M. Bueno, A.R. Fernandez-Alba, Two new competitive ELISA methods for the determination of caffeine and cotinine in wastewater and river waters, Anal. Methods 4 (2012) 3364-3371.

[70] C. Pasquet, E. Vulliet, Utilisation of an enzyme-linked immunosorbent assay (ELISA) for determination of alkylphenols in various environmental matrices. Comparison with LC-MS/MS method, Talanta 85 (2011) 2492-2497.

[71] K.C. Ahn, T. Kasagami, H.J. Tsai, N.H. Schebb, T. Ogunyoku, S.J. Gee, T.M. Young, B.D. Hammock, An immunoassay to evaluate human/environmental exposure to the antimicrobial triclocarban, Environ. Sci. Technol. 46 (2012) 374-381.

[72] S.R. Webb, H. Lee, J.C. Hall, Cloning and expression in Escherichia coli of an anti-cyclohexanedione single-chain variable antibody fragment and comparison to the parent monoclonal antibody, J. Agric. Food Chem. 45 (1997) 535-541.

[73] S. Park, D.H. Lee, J.G. Park, Y.T. Lee, J. Chung, A sensitive enzyme immunoassay for measuring cotinine in passive smokers, Clin. Chim. Acta 411 (2010) $1238-1242$.

[74] K. Pan, H. Wang, H.B. Zhang, H.W. Liu, H.T. Lei, L. Huang, Y.M. Sun, Production and characterization of single chain Fv directed against beta(2)-agonist clenbuterol, J. Agric. Food Chem. 54 (2006) 6654-6659.

[75] Z. Wang, X. Liang, K. Wen, S. Zhang, C. Li, J. Shen, A highly sensitive and classspecific fluorescence polarisation assay for sulphonamides based on dihydropteroate synthase, Biotechnol. Biochem. 70 (2015) 1-4.

[76] N.A. Lee, I.R. Kennedy, Environmental monitoring of pesticides by immunoanalytical techniques: validation, current status, and future perspectives, J. AOAC Int. 84 (2001) 1393-1406.

[77] H. Obana, M. Okihashi, K. Akutsu, Y. Kitagawa, S. Hori, Determination of neonicotinoid pesticide residues in vegetables and fruits with solid phase extraction and liquid chromatography mass spectrometry, J. Agric. Food Chem. 51 (2003) 2501-2505.

[78] M. Anastassiades, K. Mastovska, S.J. Lehotay, Evaluation of analyte protectants to improve gas chromatographic analysis of pesticides, J. Chromatogr. A 1015 (2003) 163-184.

[79] P.L.W.S. Mark Lee, Comparison of the atomic emission detector to other element-selective detectors for the gas chromatographic analysis of pesticide residues, J. Agric. Food Chem. 39 (1991) 2192-2199.

[80] N. Graziano, M.J. McGuire, A. Roberson, C. Adams, H. Jiang, N. Blute, 2004 national atrazine occurrence monitoring program using the Abraxis ELISA method, Environ. Sci. Technol. 40 (2006) 1163-1171.

[81] P. Peippo, V. Hagren, T. Lovgren, M. Tuomola, Rapid time-resolved fluoroimmunoassay for the screening of narasin and salinomycin residues in poultry and eggs, J. Agric. Food Chem. 52 (2004) 1824-1828.

[82] J.Z. Shen, Z. Zhang, Y. Yao, W.M. Shi, Y.B. Liu, S.X. Zhang, Time-resolved fluoroimmunoassay for ractopamine in swine tissue, Anal. Bioanal. Chem. 387 (2007) 1561-1564.

[83] H.F. Jiang, G.L. Wang, W.Z. Zhang, X.Y. Liu, Z.Q. Ye, D.Y. Jin, J.L. Yuan, Z.G. Liu, Preparation and time-resolved luminescence bioassay application of multicolor luminescent lanthanide nanoparticles, J. Fluoresc. 20 (2010) 321-328.

[84] K.C. Monika Wortberg, Kerstin Strupat, Franz Hillenkamp, A new nonenzymatic tracer for time-resolved fluoroimmunoassay of triazine herbicides, Fresenius J. Anal. Chem. 348 (1994) 240-245. 
[85] T. Korpimaki, V. Hagren, E.C. Brockmann, M. Tuomola, Generic lanthanide fluoroimmunoassay for the simultaneous screening of 18 sulfonamides using an engineered antibody, Anal. Chem. 76 (2004) 3091-3098.

[86] Z. Zhang, J.F. Liu, B. Shao, G.B. Jiang, Time-resolved fluoroimmunoassay as an advantageous approach for highly efficient determination of sulfonamides in environmental waters, Environ. Sci.Technol 44 (2010) 1030-1035.

[87] Z. Zhang, J.F. Liu, T.T. Feng, Y. Yao, L.H. Gao, G.B. Jiang, Time-resolved fluoroimmunoassay as an advantageous analytical method for assessing the total concentration and environmental risk of fluoroquinolones in surface waters Environ. Sci. Technol. 47 (2013) 454-462.

[88] J.D. Byer, J. Struger, P. Klawunn, A. Todd, E. Sverko, Low cost monitoring of glyphosate in surface waters using the ELISA method: an evaluation, Environ. Sci. Technol. 42 (2008) 6052-6057.

[89] G.-M. Miguel Angel, Rosa Puchades, Angel Maquieira, On-line immunoanalysis for environmental pollutants: from batch assays to automated sensors, Trac Trends Anal. Chem. 18 (1999) 204-218.

[90] N. Sanvicens, I. Mannelli, J.P. Salvador, E. Valera, M.P. Marco, Biosensors for pharmaceuticals based on novel technology, Trac Trends Anal. Chem. 30 (2011) 541-553.

[91] S. Rodriguez-Mozaz, M.P. Marco, M.J.L. de Alda, D. Barcelo, Biosensors for environmental monitoring of endocrine disruptors: a review article, Anal. Bioanal. Chem. 378 (2004) 588-598.

[92] M.A. Gonzalez-Martinez, R. Puchades, A. Maquieira, Optical immunosensors for environmental monitoring: how far have we come? Anal. Bioanal. Chem. 387 (2007) 205-218.

[93] J. Wang, Electrochemical nucleic acid biosensors, Anal. Chim. Acta 469 (2002) 63-71.

[94] X.S. Jiang, D.Y. Li, X. Xu, Y.B. Ying, Y.B. Li, Z.Z. Ye, J.P. Wang, Immunosensors for detection of pesticide residues, Biosens. Bioelectron. 23 (2008) 1577-1587.

[95] C. McDonagh, C.S. Burke, B.D. MacCraith, Optical chemical sensors, Chem. Rev. 108 (2008) 400-422.

[96] M. Hasanzadeh, N. Shadjou, M. de la Guardia, Iron and iron-oxide magnetic nanoparticles as signal-amplification elements in electrochemical biosensing, Trac-Trends Anal. Chem. 72 (2015) 1-9.

[97] P. Sharma, K. Sablok, V. Bhalla, C.R. Suri, A novel disposable electrochemical immunosensor for phenyl urea herbicide diuron, Biosens. Bioelectron 26 (2011) 4209-4212.

[98] K. Grennan, G. Strachan, A.J. Porter, A.J. Killard, M.R. Smyth, Atrazine analysis using an amperometric immunosensor based on single-chain antibody fragments and regeneration-free multi-calibrant measurement, Anal. Chim. Acta 500 (2003) 287-298.

[99] E. Mallat, C. Barzen, R. Abuknesha, G. Gauglitz, D. Barcelo, Fast determination of paraquat residues in water by an optical immunosensor and validation using capillary electrophoresis-ultraviolet detection, Anal. Chim. Acta 427 (2001) 165-171.

[100] C. Barzen, A. Brecht, G. Gauglitz, Optical multiple-analyte immunosensor for water pollution control, Biosens. Bioelectron. 17 (2002) 289-295.

[101] J. Tschmelak, G. Proll, G. Gauglitz, Immunosensor for estrone with an equa limit of detection as common analytical methods, Anal. Bioanal. Chem. 378 (2004) 744-745.

[102] J. Tschmelak, G. Proll, G. Gauglitz, Ultra-sensitive fully automated immunoassay for detection of propanil in aqueous samples: steps of progress toward sub-nanogram per liter detection, Anal. Bioanal. Chem. 379 (2004) 1004-1012.

[103] S. Rodriguez-Mozaz, M.L. de Alda, D. Barcelo, Analysis of bisphenol A in natural waters by means of an optical immunosensor, Water Res. 39 (2005) $5071-5079$

[104] E.S. Bromage, G.G. Vadas, E. Harvey, M.A. Unger, S.L. Kaattari, Validation of an antibody-based biosensor for rapid quantification of 2,4,6-trinitrotoluene (TNT) contamination in ground water and river water, Environ. Sci. Technol. 41 (2007) 7067-7072.

[105] E. Benito-Pena, M.C. Moreno-Bondi, G. Orellana, K. Maquieira, A. Van Amerongen, Development of a novel and automated fluorescent immunoassay for the analysis of beta-lactam antibiotics, J. Agric. Food Chem. 53 (2005) 6635-6642.

[106] N. Yildirim, F. Long, C. Gao, M. He, H.C. Shi, A.Z. Gu, Aptamer-based optical biosensor for rapid and sensitive detection of 17 beta-estradiol in water samples, Environ. Sci. Technol. 46 (2012) 3288-3294.

[107] K. Hegnerova, M. Piliarik, M. Steinbachova, Z. Flegelova, H. Cernohorska, J. Homola, Detection of bisphenol A using a novel surface plasmon resonance biosensor, Anal. Bioanal. Chem. 398 (2010) 1963-1966.

[108] A. Ivanov, G. Evtugyn, H. Budnikov, S. Girotti, S. Ghini, E. Ferri, A. Montoya, J.V. Mercader, Amperometric immunoassay of azinphos-methyl in water and honeybees based on indirect competitive ELISA, Anal. Lett. 41 (2008) 392-405.

[109] E.V. Melikhova, E.N. Kalmykova, S.A. Eremin, T.N. Ermolaeva, Using a piezoelectric flow immunosensor for determining sulfamethoxazole in environmental samples, J. Anal. Chem. 61 (2006) 687-693. 